\title{
END OF LIFE TREATMENT COSTS FOR A COMPUTER IN COSTA RICA
}

\author{
Lilliana Abarca ${ }^{I}$ \\ Floria Roa $^{2}$ \\ Victoria Rudin ${ }^{3}$ \\ ${ }^{I}$ WASTE, Netherlands \\ ${ }^{2}$ Costa Rica Institute of Technology \\ ${ }^{3}$ ACEPESA, Costa Rica
}

\begin{abstract}
In Costa Rica, the lack of concrete solutions for electronic waste led a group of stakeholders to request bilateral aid from the Dutch Sustainable Development Agreements programme to address this problem in a systematic way. Since 2002, this group of stakeholders has formed a technical committee and engaged key national ministries, and the private sector, in a process to arrive at a sustainable, reliable, and responsible strategy for management of wastes, supported by a Dutch NGO, WASTE.
\end{abstract}

"National Strategy for an integrated and sustainable management of wastes from electronic and electric equipment in Costa Rica" is the result of six years of policy development and practical experimentation. The management approach includes:

1. Analysis of technical aspects for the waste collection, dismantling, storage, transport and treatment

2. An institutional approach is based on a participatory planning and decision-making process which has involved all stakeholders.

3. Development and negotiation of the National Decree for a National System for the Management of Special Wastes has been on the agenda of the project. Both the failures and the successes in relation to the decree offer many lessons for other countries and regional governments.

4. The programme has invited the participation of citizens and businesses, in designing the opportunities for the responsible disposal of electronic wastes from the social perspective.

5. The project has a point of departure based on extended producer responsibility (EPR) translated and adapted to the Costa Rican context, meaning that some or all of the waste management costs must be included in the price of the product. To our knowledge, this is the first example of an EPR approach to WEEE in a South country, supported by a development co-operation project.

This paper is a practical work on a technical problem in which a different type of international cooperation was applied in order to find solutions for the problem presented. 


\section{INTRODUCTION}

The waste of electric and electronic equipment (WEEE) has captured the attention of environmentalists all over the world. The problem of this type of waste is related to the complexities of the materials from which those equipments are produced, including inert materials as well as toxic ones such as: lead, copper, nickel, cadmium, mercury, among others.

The aim of any waste management programme is to recuperate most of them to be recycled in order to diminish the impact on the environment and improve the efficiency of those materials.

ACEPESA and the Costa Rica Institute of Technology in Costa Rica and WASTE in the Netherlands, decided to analyse the situation of the so called grey waste streams (computers, accessories and communication equipments) in order to set up an strategy for the waste management. This strategy should include: legal, economical, institutional, technicalenvironmental and socio-cultural aspects.

The starting point was to analyse the existing systems in developed countries with a strong environmental commitment, and the Netherlands was chosen due to its strong drive on sustainable issues and the well-proven and mature WEEE management system based on Extended Producer Responsibility (Figure 1).

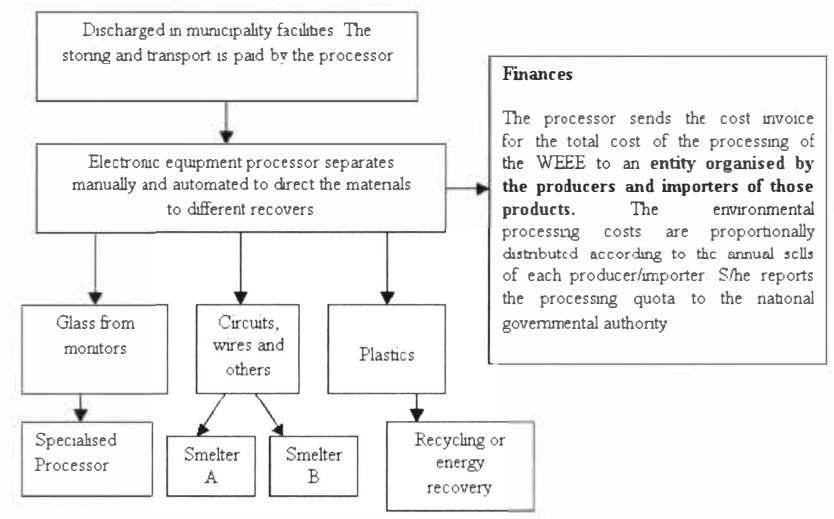

Figure 1 Dutch WEEE management system.

The system is financed by the consumers through an invisible fee that covers historic equipment (equipment sold before the system was established, therefore the end of life treatment cost is not covered), orphan equipment (equipment coming from a producer/importer that is not in the market anymore) and equipment coming from producers/importers that are not associated to any entity (free riders).though the organizations makes efforts to include them in the association in order to reduce independent producers/importers. 
Contrary to the situation of developed countries, Costa Rica doesn't have a WEEE management system; many types of equipment are stored in the institutions or in the houses, practice that has favoured (temporarily) the development of the WEEE strategy.

In low-income economy countries the recovery of materials has been done with minimum safety precautions. The metals are recuperated by heating or combustion with open fires with all the health risks for the ones performing the activity, soil, air and waster have been polluted by the dioxins and furans generated. Different environmentalists have reported these situations as well as the trans-bordering of this type of waste from developed to developing countries, transferring the problem to countries that don't have treatment technologies. Many of the export of these goods are covered by donations of assets with economical value.

\section{COSTA RICA PILOT EXPERIENCE}

The actions proposed for the WEEE system incorporates different components as mentioned. A description of each one is presented.

Legal: A Decree has been developed and is about to be approved in which it is established the creation of a Regulation for the creation of a National special wastes system.

It establishes the responsibilities of the Ministry of Energy and Environment, the municipalities and the universities and research centres.

Technical/operational/environmental: Setting up an organisation that provides the dismantling service to the following parts: monitors, electronic circuit wafers, wires, plastics, copper, aluminium, and ferrous metals.

Civil society: Societal awareness in order to develop a sustainable system.

Finances: A pilot plan was developed in order to analyse the costs of an end of life treatment for a computer, as a departing cost point for the moment the system is established. The plan analysed storage, transport, disassembly, treatment (national and international), and final disposal.

The international treatment was done in the Netherlands and in USA.

\section{CONCLUSIONS}

The results presented are preliminary, and the objective of the disassembly pilot plan was to have a broad idea of the times required to disassemble a personal computer and accessories, and the costs involved. More precise data should be developed in the future when the system is established. 
The preliminary results are presented in the poster in the Eco-Tech 07 Conference, University of Kalmar, Sweden.

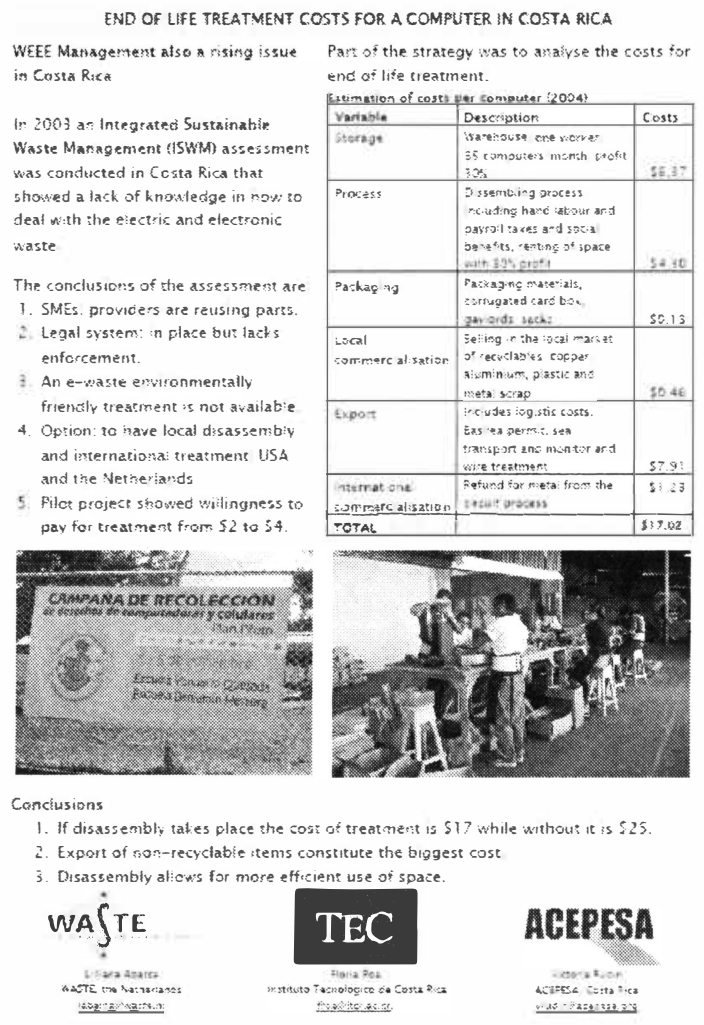

\section{BIBLIOGRAPHY}

Diagnóstico de la situación del manejo integrado y sostenible de los desechos electrónicos. ACEPESA-ITCR-CICR-MINAE, Costa Rica, Agosto, 2003

Comunidad Autónoma del País Vasco. "Monografia sobre aparatos eléctricos y electrónicos", 2002.

http://www.svtc.org/cleancc/pubs/ppc-ttvl.pdf

Ogilvie, S.M. AEA Technology, WEEE \& Hazardous Waste: A report produced for DEFRA(Department 